\title{
NOTE
}

\section{Lobster movements in response to a hurricane}

\author{
Steven H. Jury *, W. Huntting Howell, Winsor H. Watson III **
}

Zoology Department, Center for Marine Biology, University of New Hampshire, Durham, New Hampshire 03824, USA

\begin{abstract}
There are several anecdotal reports of the American lobster Homarus americanus moving to deeper water, or suffering increased mortality, in response to storm events. It has also been reported that changes in salinity and temperature, similar to those resulting from storm events, can elicit avoidance behaviors. In 1991, during an ongoing lobster study, Hurricane Bob caused a substantial drop in salinity in the Great Bay Estuary, New Hamphire, USA. This freshet, and possibly related environmental perturbations, was associated with increased movement of lobsters down the estuary toward the coast and a rise in catch in areas closer to the coast. Thus, our data support the hypothesis that storms can induce movements of lobsters and subsequent transient shifts in the demographics of the lobster population.
\end{abstract}

KEY WORDS: Estuary $\cdot$ Hurricane $\cdot$ Lobster $\cdot$ Movements

It is generally accepted that seasonal changes in the physico-chemical environment, particularly temperature and salinity, affect the catch and movements of the American lobster Homarus americanus (McCleese \& Wilder 1958, Krouse 1973, Munro \& Therriault 1983 , Reynolds \& Casterlin 1985, Ennis 1986, Robichaud \& Campbell 1991, Campbell 1992, DiBacco \& Pringle 1992, W. Watson, H. Howell \& A. Vetrovs unpubl. data). Intense storms often cause transient drops in salinity and changes in water temperature, and several anecdotal reports suggest that these events trigger movements of lobsters. For example, both Cooper et al. (1975) and Ennis (1984) observed that adult lobsters in inshore regions undertake small-scale movements downslope from shallow waters to deeper areas in response to stormy conditions. It was also noted that when these storms occur during the summer, the lobsters usually return to shallow waters shortly after the

\footnotetext{
- Present address: SEA Division, NOAA, N/ORCA 1, SSMC 4, 1305 East West Hwy, Silver Spring, Maryland 20910, USA

- Addressee for correspondence
}

event (Ennis 1984). After particularly severe storms, there have been reports of many dead lobsters washed up on beaches in New Brunswick (Prince 1897) and on Prince Edward Island, Canada (D. J. Scarratt pers. comm. reported in Drinkwater et al. 1991), and the rapid declines in salinity associated with some storms have reportedly caused lobster mortalities when the freshwater layer reached low enough to cover their burrows (Thomas 1968, Thomas \& White 1969). Taken together, these reports suggest that during storms lobsters move to deeper water which is colder, calmer and has a higher salinity. The purpose of this study was to collect movement and catch data which might improve our understanding of this behavior.

Catastrophic storms, particularly hurricanes, may perturb the inshore environment by several means including increased turbidity (Tabb \& Jones 1962, Saloman \& Naughton 1977), depletion of oxygen due to decomposition of exposed or resuspended organic sediments or detritus (Tabb \& Jones 1962, Saloman \& Naughton 1977, Knott \& Martore 1991), physical disturbance due to tidal, wind and wave action (Saloman \& Naughton 1977, Yeo \& Risk 1979, Lowery 1992), and low salinities caused by heavy rains and runoff (Saloman \& Naughton 1977, Knott \& Martore 1991). The most obvious environmental impact of severe storms (e.g. hurricanes) on temperate estuaries is the occurrence of freshets (Witham et al. 1968, Boesch et al. 1976, Knott \& Martore 1991) which cause a rapid, and large, drop in salinity.

Lobsters are limited osmoregulators (Dall 1970) and when they are exposed to decreased salinity there is a drop in blood osmolarity and an increase in the rate of oxygen consumption (Jury et al. 1994a). It has also been demonstrated that lobsters actively avoid salinities below approximately 20 to $17 \mathrm{ppt}$ (Reynolds \& Casterlin 1985, Jury et al. 1994b). The upper lethal temperatures for adults range from 20.6 to $30.5^{\circ} \mathrm{C}$ and 
the lower lethal salinities range from 6.0 to $16.4 \mathrm{ppt}$ (McCleese 1956). The lethal salinity $\left(L_{50}\right)$ for Stage I lobsters is approximately $17 \mathrm{ppt}$ and this decreases to between 10.5 and 12 ppt in Stages IV and V (Charmantier et al. 1988). Newly hatched larvae avoid salinities of less than 21.4 ppt (Scarrat \& Raine 1967) and the metabolic stress of low salinity is thought to be greatest for larvae and molting individuals (Scarrat \& Raine 1967, Charmantier et al. 1988). Finally, the warmer the water, the less tolerant lobsters are to drops in salinity (McLeese 1956). Therefore, summer storm events are likely to result in potentially lethal changes in the ambient salinity and temperature for inshore lobsters.

On August 19, 1991, Hurricane Bob passed over the New Hampshire, USA, coast and the intense rains associated with the storm caused the salinity in the upper Great Bay Estuary, New Hampshire, to drop to close to $0 \mathrm{ppt}_{\text {; }}$ and, it remained below $10 \mathrm{ppt}$ for more than 1 wk (Fig. 1). After a lag of approximately $4 \mathrm{~d}$, freshets from the 7 rivers emptying into the estuary even caused a drop in salinity from 31 to $20 \mathrm{ppt}$ at the coastai terminus of the Great Bay estuarine system. There was also a concurrent decrease in temperature in the upper estuary, but not in the lower estuary (Fig. 1). Because this hurricane occurred during an ongoing study of the temporal and spatial distribution of Homarus americanus in this estuary, we have been able to document its effects on lobster movements and catch per unit effort (CPUE).

Although our data support the notion that severe storms induce lobster movements (Cooper et al. 1975, Ennis 1984), this study was not intentionally designed to test the effect of storms on lobster movements and catch. Indeed, logistical problems abound in studies of storm events due to their unpredictable nature, diffi- culty in finding controls, and often the inability to sample during the storm (Boesch et al. 1976). Nonetheless, the data presented have been interpreted conservatively and support the limited observational data showing that lobsters move short distances in response to episodic environmental perturbations caused by storms.

Methods. Lobsters were trapped at 5 sampling sites within the Great Bay Estuary and coastal waters of New Hampshire (Fig. 2). All were caught in standard, vinyl-coated wire commercial traps baited with herring, and tended 2 to 3 times per week. Lobsters were measured, sexed, molt-staged, tagged using individually numbered modified sphyrion tags (Scarratt 1970 ), and released immediately at the same location. Some additional tagging and trapping was carried out on commercial lobster boats and the tag number and location of recaptured animals was reported by local lobstermen or University of New Hampshire (UNH) personnel. As all lobsters below the legal size limit were immediately released, some lobsters were recaptured (and their location reported) on several occasions. Bottom salinity and temperature were recorded daily (Fig. 1) in the upper Great Bay (Endeco Model 972 CTD meter; daily mean computed from hourly readings) and at the UNH Coastal Marine Laboratory near the mouth of Portsmouth Harbor, New Hampshire (precision mercury thermometer and a temperature compensated refractometer). In the estuary both temperature and salinity exhibited tidal fluctuations with a range of up to $5^{\circ} \mathrm{C}$ and $5 \mathrm{ppt}$, respectively. The magnitude of this tidal variability diminished toward the coast

To examine hurricane effects, lobster data collected in 1989, 1990, and 1992 were compared with data collected in 1991, the year of Hurricane Bob. For each year directional movement information was extracted
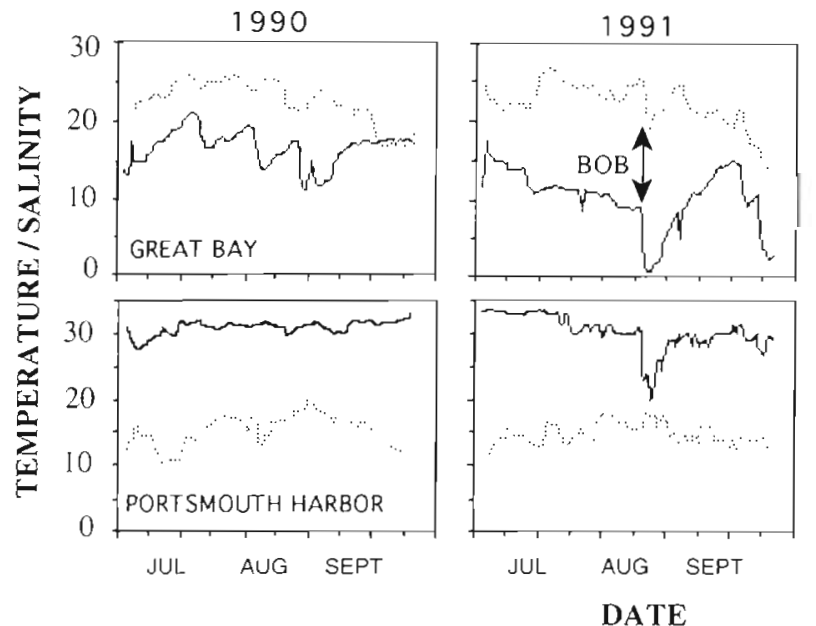

(July I-September 30)

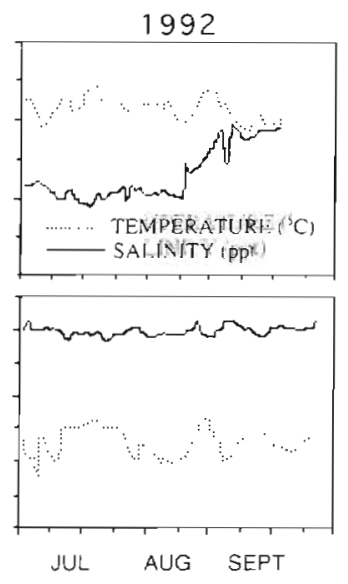

Fig. 1. Daily salinity (ppt) and temperature $\left({ }^{\circ} \mathrm{C}\right)$ in the Great Bay Estuary and New Hampshire Coastal Waters (Portsmouth Harbor) between July 1 and September 30, 1990-1992. BOB: hurricane, August 19, 1991 


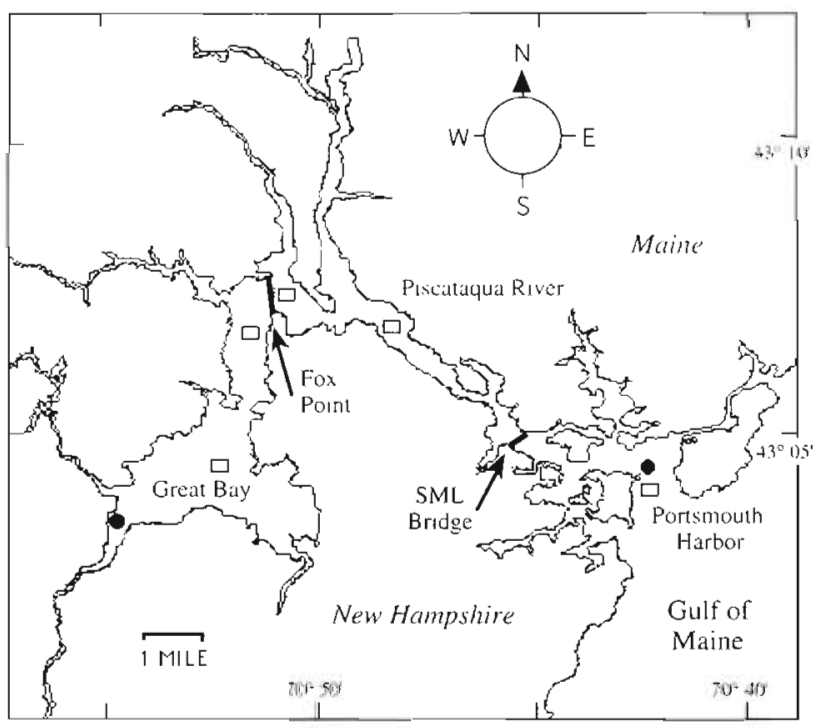

Fig. 2. Locations of salinity and temperature monitoring (•); and trapping (ㅁ) sites in the Great Bay Estuary, New Hampshire, USA. Dark bars at Fox Point and the SML Bridge indicate where we divided the estuary into upper, middle and lower sections to facilitate data analyses

only from individuals that were tagged between July 1 and August 20 and subsequently recaptured between August 21 and September 30. This time frame was chosen to bracket the time of lowest salinity associated with the hurricane. The numbers of recaptured lobsters that had not moved, or that had moved either upstream or downstream relative to their tagging location, were compared within and between years using chi-squared contingency tests (Sokal \& Rohlf 1981). We were also able to 'track' the movements of individual lobsters ( $n=13$ ) that were recaptured on multiple occasions before and after the storm in 1991.

CPUE, measured as the number of lobsters caught per trap haul, was determined by dividing the combined weekly catch from our own traps by the combined number of traps fished during that week. Typically, we pulled our traps 2 to 3 times each week and we had 3 to 4 traps at each sampling site. Data from adjacent sampling locations (Fig. 2) were pooled in order to group the data into upper, middle, and lower estuarine areas, which yielded twice as many trap hauls at the estuary and river stations than at the coastal site (upper $=522$, middle $=590$, lower $=322$ ) . Again, a month long window of time before and after Hurricane Bob was established for comparison between years from 1989 to 1992.

Results. Lobster movements after Hurricane Bob in 1991 were markedly different than they were in 1989 , 1990, and 1992 (Fig. 3). First, compared with other years, a significantly greater number than expected had moved from their tag/release location during this

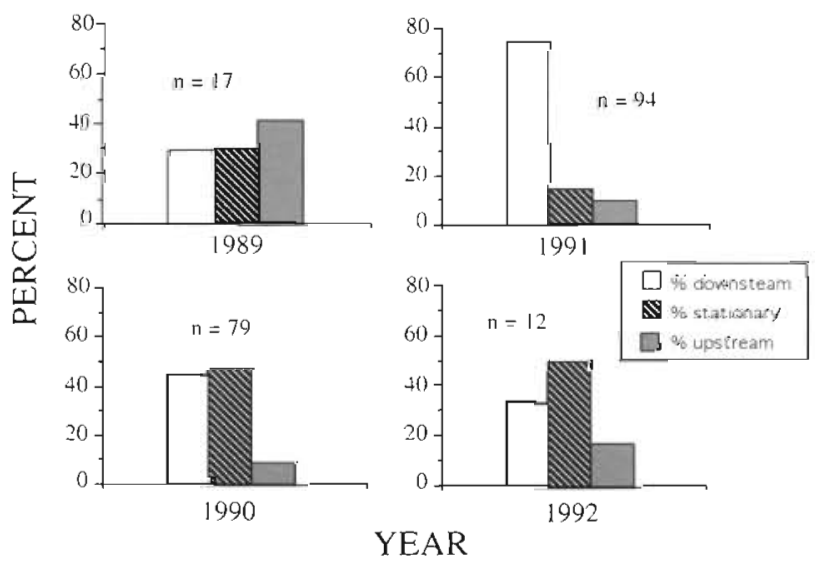

Fig. 3. Movements of tagged lobsters Homarus americanus in the Great Bay Estuary between July and September for 1989 to 1992 . Percent of lobsters which moved in a given direction (upstream, downstream) or didn't move at all (stationary) was determined by analysis of individuals tagged during the $30 \mathrm{~d}$ prior to August 19, 1991 (when Hurricane Bob occurred), and subsequently recaptured during the following $30 \mathrm{~d}$

period of time (compare hatched bars, Fig. 3; p < 0.001 ). In a typical year, between 50 and $70 \%$ of the lobsters tagged during the summer were found in a new location a month later, but during 1991 more than $80 \%$ of the individuals tagged moved. Second, of the lobsters that did move, a greater number than expected moved downstream toward the coast than upstream into the estuary $(p<0.001)$. While it is common for more lobsters to move downstream than upstream at this time of the year (Watson \& Howell unpubl. data), the number of individuals moving downstream was significantly greater in 1991 than in 1989, 1990, or 1992 (Fig. 3). The lower number of recaptured lobsters in 1989 (when we were beginning our tagging program) and 1992 (when the program was ending) most likely reflect poorer communication with lobstermen, not a change in the number tagged or catchability. Finally, the limited data obtained from the lobsters that were released and then recaptured on several subsequent occasions also indicate a general downstream movement associated with the hurricane. In the months preceding the storm, 8 of these 13 lobsters were repeatedly recaptured near their original tagging locations. Following the storm, all subsequent recaptures were made some distance downstream in a deeper, higher salinity location. Thus, all of our movement data, based upon both single and multiple recaptures, indicate that Hurricane Bob caused a general pattern of movement down the estuary.

The CPUE data also support the contention that lobsters were moving downstream after the storm (Fig. 4). In 1991, there was an increase in catch in the lower 


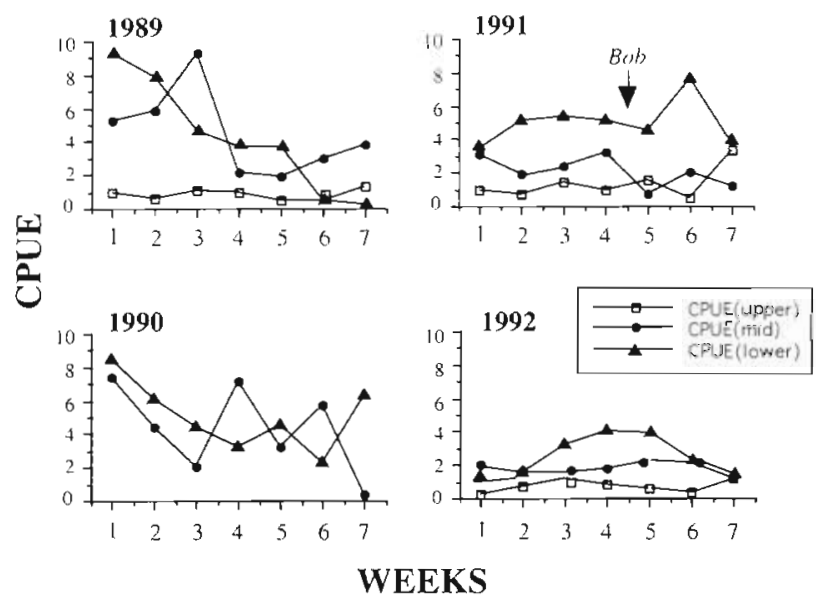

Fig. 4. Weekly variations in catch per unit effort (CPUE) during the summers of 1989 to 1992 . The numbers on the $x$-axis refer to the number of the week, starting with the last week in July and ending with the second week in September. Catch data from the upper estuary in 1990 was not continuous or reliable enough to be included. Bob: hurricane, August 1991

and middle estuary approximately $2 \mathrm{wk}$ after the storm. While it is possible that these changes may have been due to natural variation, the large increase in CPUE in the lower estuary was not evident in the other years during the same time period. It is also possible that catchability increased because activity levels were elevated as a direct, or indirect, result of the storm. Nonetheless, if the observed results were due solely to increased catchability then one would expect increased CPUE throughout the estuary and not just in the downstream areas. The lag time of approximately 2 wk for the CPUE increase after the storm (Fig. 4) may reflect the time it took lobsters to travel downstream. Alternatively it may reflect increased feeding activity of locally abundant lobsters after the environmental conditions returned to normal. Unfortunately the CPUE data are equivocal, but in our opinion the downstream movement shown in Fig. 3 may well have resulted in an increased abundance of lobsters in the lower estuary, which in turn caused the CPUE to increase in this area. It is also interesting that the CPUE in the lower estuary rebounded to normal levels later in the fall, possibly indicating that individuals returned to previously occupied sites following a summer storm; similar to post-storm SCUBA observations in other areas (Ennis 1984, Knott \& Martore 1991).

Discussion. While the mechanisms and ultimate cause of the observed downstream movement of lobsters are uncertain, adverse environmental conditions caused by the storm runoff appear to be the most plausible explanation. It is likely that lobsters inhabiting estuaries are near the extremes of their zone of tol- erance (McCleese 1956, MacKenzie \& Moring 1985). If we assume that waters were fully oxygenated in the Great Bay Estuary, which is tidally well mixed so that hypoxia is rarely recorded (Short 1992), then we may extrapolate the lethal levels of temperature and salinity for lobsters acclimated to pre-storm conditions [based upon the findings of McCleese (1956)] to be from 27.8 to $30.5^{\circ} \mathrm{C}$ and from 8.2 to $16.4 \mathrm{ppt}$. The drop in temperature and salinity caused by Hurricane Bob may not have reached lethal levels in the lower estuary (where the salinities were comparatively high and temperatures low), but they almost certainly did in the upper estuary (where the salinities were comparatively low and temperatures high).

It is unknown how the severe and unseasonal reductions in temperature and salinity caused by storms affect lobster behavior. Lobsters '... are extremely tolerant of abrupt temperature changes and within certain ranges can survive rapid increases of $16^{\circ} \mathrm{C}$ and decreases of $20^{\circ} \mathrm{C}^{\prime}$ (Aiken \& Waddy 1986). However, smaller temperature changes may be important environmental cues that trigger certain behavioral and/or physiological responses (McCleese \& Wilder 1958), including the well-documented seasonal migrations of spiny lobsters Panulirus argus (Kanciruk \& Herrnkind 1978). In contrast, the low salinities which resulted from the hurricane were potentially lethal in some areas and it is likely that lobsters either moved to deeper, more coastal waters where the salinity was higher, or died. Although we have no mortality data, we believe that it is likely that some lobsters, particularly those near molting which extends from June through September in this area (Howell \& Watson unpubl data), died as a result of the storm. The observed general downstream movements of lobsters provides evidence that at least some individuals attempted to avoid the low salinities resulting from the storm. This is consistent with our laboratory studies showing that lobsters actively avoid low salinity water before it reaches levels that are potentially lethal (Jury et al. 1994b)

Spiny lobsters also appear to avoid low salinity conditions associated with intense storms. The effect of a freshet on spiny lobsters was observed in the St. Lucie Estuary, Florida, USA (Witham et al. 1968) when Hurricane Alma caused the salinity to drop to as low as 6 ppt. This low salinity event interrupted the normal influx of spiny lobster pueruli, and they returned only after the salinity had increased to an average of about 23 ppt. In addition, subadult and juvenile lobsters (mean size $=46.7 \mathrm{~mm} \mathrm{CL}$ ) were consistently captured within the estuary in the months preceding the storm, but very few were caught at the same locations in the months after the storm. Thus, it appears as if spiny lobsters respond to transient drops in salinity in a manner 
closely resembling that which we observed for Homarus americanus.

At the population level, Sutcliffe (1973) found a positive correlation between discharge from the St. Lawrence River, Canada, and landings of American lobsters in Quebec, Canada, 9 yr later. He speculated that in years where there was greater discharge, there were more nutrients added, and this resulted in more food for larval lobsters. Subsequently, Sheldon et al. (1982) suggested that the underlying mechanism may be associated with discharge-related temperature changes rather than nutrient loading. More recently, Drinkwater et al. (1991) have shown that the relationship between river discharge and landings first reported by Sutcliffe (1973) has not held since 1984, and they suggest that lobster populations may be responding to more 'widespread environmental or ecosystem changes'. Whatever the underlying mechanism, the close relationship between river discharge and lobster landings that held for about $40 \mathrm{yr}$ is provocative, and suggests that seasonal variations in river runoff can be directly, or indirectly, affecting recruitment to local stocks.

The effect of episodic environmental disturbance caused by storms may be more pertinent to the life history of estuarine and coastal decapods in temperate areas than the paucity of literature suggests. In the Great Bay Estuary the average monthly precipitation for the months of July, August, and September from 1981 to 1990 was $8.53 \mathrm{~cm} \pm 4.57 \mathrm{SD}$ (based upon National Weather Service monitoring in Durham, $\mathrm{NH}$; NOAA 1981-1990). However, in this $10 \mathrm{yr}$ span there were 5 instances when the precipitation in any one summer month was $>14.0 \mathrm{~cm}$. During these months the salinity in the Great Bay Estuary probably dropped significantly, and may have triggered movements similar to those reported in this study. Thus, these relatively common environmental disturbances are likely to have both a short-and long-term impact on the distribution and/or recruitment of estuarine and nearshore decapods, and they should be considered more thoroughly in future studies.

Acknowledgements. We extend special thanks to the faculty and staff of the Zoology Department, Jackson Estuarine Laboratory, and the Coastal Marine Laboratory of the University of New Hampshire. In particular, we thank Rich Langan for providing temperature and salinity data and continuously helping us with our boats, Joanne Delaney for accurately measuring temperature and salinity at the Coastal Marine Laboratory, and all of the students who entered thousands of pieces of data during the past $5 \mathrm{yr}$. We are especially indebted to all the New Hampshire lobstermen who provided tag/ recapture data. This manuscript was improved by the comments of several anonymous reviewers. This is contribution no. 309 of the Center for Marine Biology/Jackson Estuarine Laboratory series.

\section{LITERATURE CITED}

Aiken, D. E., Waddy, S. L. (1986). Environmental influence on recruitment of the American lobster, Homarus americanus: a perspective. Can. J. Fish. Aquat. Sci. 43: 2258-2270

Boesch, D. F., Diaz, R. J., Virnstein, R. W. (1976). Effects of tropical storm Agnes on soft-bottom macrobenthic communities of the James and York estuaries and the Lower Chesapeake Bay. Chesapeake Sci. 17(4): 246-259

Campbell, A. (1992). Characteristics of the American lobster fishery of Grand Manan, New Brunswick, Canada. N. Am. J. Fish. Manage. 12: 139-150

Charmantier, G., Charmantier-Daures, M., Boouaricha, N., Thuet, L. P., Aiken, D. E., Trilles, J. P. (1988). Ontogeny of osmoregulation and salinity tolerance in two decapod crustaceans: Homarus americanus and Penaeus japonicus. Biol. Bull. 175: 102-110

Cooper, R. A., Clifford, R. A., Newell, C. D. (1975). Seasonal abundance of the American lobster, Homarus americanus, in the Boothbay Region of Maine. Trans. Am. Fish. Soc. 4: 669-674

Dall, W. (1970). Osmoregulation in the lobster Homarus americanus. J. Fish. Res. Bd Can. 27: 1123-1130

Dibacco, C., Pringle, J. D. (1992). Larval lobster (Homarus americanus, $\mathrm{H}$. Milne Edwards, 1837) distribution in a protected Scotian shelf bay. J. Shellfish Res. 11(1): 81-84

Drinkwater, K. F., Harding, G. C., Vass, W. P., Gauthier, D. (1991). The relationship of Quebec lobster landings to freshwater runoff and wind storms. In: Therriault, J.-C. (ed.) The Gulf of St. Lawrence: small ocean or big estuary? Can. Spec. Publ. Fish. Aquat. Sci. 113: 179-187

Ennis, G. P. (1984). Small-scale seasonal movements of the American lobster Homarus americanus. Trans. Am. Fish. Soc. $113: 336-338$

Ennis, G. P. (1986). Stock definition, recruitment variability, and larval recruitment process in the American lobster, Fomarus americanus: a review. Can. J. Fish. Aquat. Sci. 43: 2072-2084

Jury, S. H., Kinnison, M. T., Howell, W. H., Watson, W. H. (1994a). The effects of reduced salinity on lobster (Homarus americanus: Milne-Edwards) metabolism: implications for estuarine populations. J. exp. mar. Biol. Ecol. 176: 167-185

Jury, S. H., Kinnison, M. T., Howell, W H., Watson, W. H. (1994b). The behavior of lobsters in response to reduced salinity. J. exp. mar. Biol. Ecol. 180: 23-37

Kanciruk, P., Herrnkind, W. (1978) Mass migration of spiny lobster, Panulirus argus (Crustacea: Palinuridae): behavior and environmental correlates. Bull. mar. Sci. 28(4): 601-623

Knott, D. M., Martore, R. M. (1991). The short-term effects of Hurricane Hugo on fishes and decapod crustaceans in the Ashley River and adjacent marsh creeks, South Carolina. J. coast. Res. 8: 335-356

Krouse, J. S. (1973). Maturity, sex ratio, and size composition of the natural population of American lobster, Homarus americanus, along the Maine coast. Fish. Bull. U.S. 71(1): $165-173$

Lowery, T A. (1992). Apalachicola Bay's proclivity for sediment export during hurricanes and its impact on oyster production from 1960-1985. J. Shellfish Res. 11(2): 461-466

Mackenzie, C., Moring, J. R. (1985). Species profiles: life histories and environmental requirements of coastal fishes and invertebrates (North Atlantic) - American lobster. U.S. Fish Wildl. Serv. biol. Rep. 82(11.33). U.S. Army Corps of Engineers, TR EL-82-4, U.S. Dept of the Interior, Washington, DC, p. 19 
McCleese, D. W. (1956). Effects of temperature, salinity and oxygen on the survival of the American lobster. J. Fish. Res. Bd Can, 13(2): 247-272

McCleese, D. W., Wilder, D. G. (1958). The activity and catchability of the lobster (Homarus americanus) in relation to temperature. J. Fish. Res. Bd Can. 15(6): 1345-1354

Munro, J., Therriault, F. (1983). Migrations saisonnières du homard (Homarus americanus) entre la côte et les lagunes des Iles-de-la-Madeleine. Can. J. Fish. Aquat. Sci. 40: $905-918$

National Oceanographic and Atmospheric Administration (NOAA) (1981-1990). Climatological data: annual summary New England. Vol. 93-103 (13), ISSN 0364-5339

Prince, E. E. (1897). Natural history of the lobster, with special reference to the Canadian lobster industry. 29th Ann. Rep Dept. Mar. Fish., Fish. Branch, Supplement 1, p. 16

Reynolds, W. W. Casterlin, M. E. (1985). Vagile macrofauna and the hydrographic environment of the Saco River Estuary and adjacent waters of the Gulf of Maine. Hydrobiologia 128: 207-215

Robichaud, D. A., Campbell, A. (1991). Annual and seasona] size-frequency changes of trap-caught lobsters (Homarus americanus) in the Bay of Fundy. J. NW Atlant. Fish. Sci. 11: $29-37$

Saloman, C. H., Naughton, S. P. (1977). Effects of Hurricane Eloise on the benthic fauna of Panama City Beach, Florida, USA. Mar. Biol. 42: 357-363

Scarratt, D. J. (1970). Laboratory and fjeld tests of modified sphyrion tags on lobsters (Homarus americanus). J. Fish. Res. Bd Can. 27: 257-264

Scarratt, D. J., Raine, G. E. (1967). Avoidance of low salinity by newly hatched lobster larvae. J. Fish. Res. Bd Can.

This note was presented by R. B. Forward, Beaufort, N. Carolina, USA
$24(60): 1403-1406$

Sheldon, R. W., Sutcliffe, W. H. Jr, Drinkwater, K. F. (1982) Fish production in multispecies fisheries. In: Mercer, M. C (ed.) Multispecies approaches to fisheries management advice. Can. Spec. Publ. Fish. Aquat. Sci. 59: 28-34

Short, F. T. (ed.) (1992). The ecology of the Great Bay Estuary, New Hampshire and Maine: an estuarine profile and bibliography. Coastal Ocean Program Publ., NOAA, Washington, DC, p. 222

Sokal, R. R., Rohlf, F. J. (1981). Biometry. W. H. Freeman, San Francisco

Sutcliffe, W. H. Jr (1973). Correlations between seasonal river discharge and local landings of American lobster (Homarus americanus) and Atlantic halibut (Hippoglossus hippoglossus) in the Gulf of St. Lawrence. J. Fish. Res. Bd Can. 30: 856-859

Tabb, D. C., Jones, A. C. (1962). Effects of Hurricane Donna on the aquatic fauna of north Florida Bay. Trans. Am. Fish. Soc. 91(4): $375-378$

Thomas, M. L. H. (1968). Overwintering of American lobsters, Homarus americanus, in burrows in Bideford River, Prince Edward Island. J. Fish. Res. Bd Can. 25(12): 2725-2727

Thomas, M. L. H., White, G. N. (1969). Mass mortality of estuarine fauna at Bideford, P.E.I., associated with abnormally low salinities. J. Fish. Res. Bd Can. 26: 701-704

Witham, R., Ingle, R. M., Joyce, E. A. Jr (1968). Physiological and ecological studies of Panulirus argus from the St. Lucie Estuary. Tech. Series 53. Florida Board of Conservation, St. Petersburg

Yeo, R. K., Risk, M. J. (1979). Intertidal catastrophes: effects of storms and hurricanes on intertidal benthos of the Minas Basin, Bay of Fundy. J. Fish. Res. Bd Can. 36: 667-669

Manuscript first received: November 24, 1993

Revised version accepted: October 26, 1994 